\title{
FAITH IN THE TIMES OF COVID-19: INTEGRATING RELIGION IN THE FIGHT AGAINST COVID-19 IN TANZANIA
}

\author{
Thomas J. Ndaluka \\ Lecturer and Coordinator \\ Society and Religion Research Centre (SORRECE), Tanzania \\ ndaluka.thomas@udsm.ac.tz
}

\section{Magolanga Shagembe}

Assistant Lecturer in Psychology

University of Dar es Salaam, Tanzania

Secretary General of the Tanzanian Psychological Association (TAPA)

shagembe.magolanga@udsm.ac.tz

\section{Jonas Kinanda}

Assistant Lecturer in Psychology

Coordinator of the Unit of Psychology

University of Dar es Salaam, Tanzania

kinandajj@gmail.com

\section{Vendelin Simon}

Lecturer and Coordinator of the Unit of Anthropology

University of Dar es Salaam, Tanzania

vendelin.simon@yahoo.com

\begin{abstract}
When and where a crisis such as a pandemic arises, people turn to religion in pursuit/search of comfort, justifications, and explanations. This article describes the role of religion in Tanzania in the times of COVID-19. The data collected through a questionnaire from 258 participants asserts that COVID-19 increased the intensity level of religiosity in Tanzania. This was seen in peoples' participation in religious activities, i.e., religious gatherings, frequent prayers, and other religious practices. This article has established that the process of de-secularization was strong, and religion became a provider of hope, unity, solace, and socialization. Moreover, COVID-19 has also facilitated the convergence of different religions and thus ecumenism and pluralism of faiths have been strengthened in the country.
\end{abstract}

Keywords: COVID-19, de-secularization, faith, religious gathering 
"Churches are like hospitals for the soul"

Polish Deputy Prime Minister (2020)

\section{INTRODUCTION}

In African societies and particularly in Tanzania, religion and religious institutions play a dominant role in the lives of millions (Sundqvist 2017; Ndaluka 2012; Mbiti 1969; Lawi 2015). According to the 2009 survey by the Pew Forum on Religion and Public Life, 93\% of the Tanzanian population said that religion was very important in their life. This implies that for most Africans, religion and religious beliefs provide the basis for moral values, religious practices and ceremonies. Tanzanians engage in religious practices not only in the case of physical diseases, but also for social, psychological, and interpersonal problems (Lawi 2015). Regular religious participation, write Kowalczyk et al. (2020: 2671), "is connected with better emotional health outcomes".

In Tanzania, since the second half of the twentieth century, modern health interventions have been brought in by missionaries as a way of winning new converts to religion (Ndaluka 2012; Sundqvist 2017). Since then, the role of religion in the provision of health to the Tanzanian population through religious/ faith-based organizations has been significant. It is estimated that faith-based organizations provide from 30 to $70 \%$ of the health services and interventions in African countries (World Bank 2013).

In his article "In a pandemic are we more religious? Traditional practices of Catholics and the COVID-19 in southwestern Colombia", Diego Meza (2020) writes, pointing to the Colombian context, that diversity caused by adverse and unexpected events increases religiosity. He asserts that there is a correlation between fear and beliefs (ibid.). The emergence of COVID-19 in Tanzania in early 2020 brought many unprecedented apprehensions and consequently both short- and long-term socio-economic implications arose in the community. A similar observation was reported by Kowalczyk et al. (2020: 2675) and DeFranza et al. (2020), whereby the former added that "religious beliefs and practices are associated with various health aspects, such as ability to cope with a disease, recovery after hospitalization and positive attitude in a difficult situation, including health".

Evidence from literature affirms that faith can be used to help communities deal with adverse challenges and fears. In doing so, it reassures permanent security and a state of stability (Meza 2020; Kowalczyk et al. 2020). People turn towards religious beliefs to deal with social, economic, and health ramifi- 
cations resulting from calamities and diseases such as COVID-19 (Kowalczyk et al. 2020). Kowalczyk et al. (2020) add that faith or spirituality is a force that helps to overcome mental crises and facilitates adaptation to diseases. They see that COVID-19 has made people more open to their religious beliefs and religious practices (ibid.).

Meza's question is, therefore, relevant in this context. This paper intends to answer a similar question: After the emergence of COVID-19, have Tanzanians become more religious? Perhaps it is also relevant to add more questions to this: Does the emergence of COVID-19 reinstate the power of religion in Tanzania? How have religion and religious practices participated in the creation of new forms of dealing with the pandemic?

\section{COVID-19 IN THE CONTEXT OF TANZANIA}

COVID-19 was first reported in Wuhan city in China in December 2019 and rapidly spread throughout many countries in the world, including Tanzania. According to the WHO Coronavirus Dashboard, ${ }^{1}$ as of December 7, 2020 (3:47 pm CET), 66,422,058 people were infected with the virus globally, while the death toll was at $1,532,418$. The pandemic struck the Americas hard with 28,355,791 confirmed cases, Europe with 20,154,730 cases, South-East Asia with 11,114,545 cases, Eastern Mediterranean countries with 4,319,467 cases, Africa with 1,556,168 cases, and Western Pacific nations with 920,613 confirmed cases (WHO 2020).

The outbreak of COVID-19 in Tanzania was officially confirmed by the Ministry of Health, Community Development, Gender, Elderly and Children (MoHCDGEC) on March 15, 2020. The first case was reported in Arusha region, where a patient who had travelled from Belgium tested positive. As of May 2020, the country had 509 confirmed cases with 12 deaths and 183 recoveries. However, in May 2020 the government of Tanzania stopped reporting publicly the status of COVID-19 cases in the country. Despite that, the government promoted preventive measures as per WHO guidelines, such as closure of schools, social distancing, wearing of masks, hand sanitization, and frequent hand washing. The rate and level of compliance to these measures varied based on collective culture and scarcity of resources. By July 2020, the government of Tanzania had re-opened all schools, encouraging people to live a normal life with less fear of COVID-19. This step was taken by the government after realizing that the restrictions related to the pandemic and COVID-19 infection would have a devastating effect on the health and economy of the population in an unprecedented scope and magnitude, and an ongoing lockdown and closure of borders 
enforced by the government would not only paralyze the economy but also exert a severe impact on the welfare and social life of the general population.

The pandemic has raised many concerns, faith being one of the subjects addressed in this paper. COVID-19 is being regarded as the most serious public health calamity of the twenty-first century, and governments and the global community are still struggling to contain its spread. COVID-19 has reminded the society of the role that faith plays in addressing health calamities during difficult times. Although the pandemic imposed strains on faith (some religious leaders closed religious buildings in the Kagera region and Zanzibar, causing mental strains to believers questioning their religious leaders' commitment to their faith), people attempted to make adjustments within their capacities through religious practices (Kowalczyk et al. 2020). Religious doctrines and beliefs provide certain explanations and meaning to the occurrences of events such as COVID-19 (ibid.).

There are only limited studies on the connection between pandemic diseases and faith. However, there is no denial that religion is a potent and pervasive social force. The power religion generates can be an important instrument to spread but also fight pandemic diseases. While religious gatherings are known to be potential sources of virus spread, they are at the same time known to have been used in helpful ways to provide knowledge about pandemics. Often the role of religious actors is to give hope and combat fear with knowledge. Religious leaders are expected to encourage and offer prospects to their followers. They are also assumed to prepare the efforts of many other actors during the fight against epidemics. These leaders are further expected to sustain and ensure continuity of worship in life in the case of disruption and show God's compassion and care of community members. However, unlike other pandemics, COVID-19 and accompanying policies stood against religious gatherings. Thus, COVID-19 tested the faith and particularly the religious leaders who were still supposed to support those in suffering.

Without doubt religion has had an impact on the transmission of COVID-19 in numerous ways. In some cases, it has escalated the spread of the disease through religious gatherings, especially when public health measures have not been observed. At the same time, religion has slowed the spread when it has been used as an instrument to provide credible health information in a theologically trusted manner. This article concentrates on the role and outputs of religion in the time of COVID-19 in Tanzania, based on a particular set of fieldwork material and general observations. 


\section{DE-SECULARIZATION VERSUS SECULARIZATION TRENDS}

After World War II, classical secularization theorists observed a declining trend of religiosity (Gorski 2003), which was attributed to modernity. The central premise was that, as the world was modernizing, religious beliefs and practices started to be perceived as insignificant (Norris \& Inglehart 2004). Friedrich Nietzsche's statement (2020) "God is dead. God remains dead. And we have killed him" became a famous buzzword.

C. Wright Mills (1959: 32-33) writes, in the same vein:

Once the world was filled with the sacred - in thought, practice, and institutional form. After the Reformation and the Renaissance, the forces of modernization swept across the globe, and secularization, a corollary historical process, loosened the dominance of the sacred. In due course the sacred shall disappear altogether except, possibly, in the private realm.

Mills represents the viewpoint of many classical thinkers of the nineteenth century (Durkheim 1995 [1915]; Marx 1964; Weber 1963) who prophesized the decline of religious beliefs and practices in society due to modernization and technological advancement.

Weber's Protestantism thesis, for instance, declared a change of work attitude and consequently contributed to economic growth and development through the spirit of capitalism (Norris \& Inglehart 2004). Weber saw religion not only as a system of ideas, but also as informing actions in the form of rituals and symbolic ceremonies (ibid.). Weber believed that logical explanation grounded in physics, biology, and chemistry drives human reasoning and consequently leads to advancement in technology and innovation in all spheres including medicine, engineering, and manufacturing industries (Norris \& Inglehart 2004).

Karl Marx, on the other hand, thought religious beliefs and practices would wither away as the community gains true consciousness. According to Marx, this will be realized after the capitalist system has reached its climax (modernization). Although Emile Durkheim (1995) was, in turn, of the opinion that religion is the cause of social solidarity and cohesion and maintenance of order and stability, he also saw a decline in religion with the emergence of specialization in the industrialized society.

Nevertheless, the ideas of classical secularization theories and thinkers have not materialized as predicted. The claim that modernization, urbanization, rising levels of education and wealth weaken the influence of religion in society has been put to test. This steered quarters like Peter L. Berger to assert that the contemporary world is more religious than it was before modernization. According to Berger, the trend is reversed toward de-secularization because religion 
has not disappeared from the world as it was predicted before (Berger 2014). Writing about social cohesion and conflict in Tanzania, Ndaluka (2012, 2015) noted the reemergence of religion as a public domain in Tanzania. Additionally, several researchers have shown that the times of public and personal crises bring along particular modes of religiosity (Ganiel \& Winkel \& Monnot 2014).

Norris and Inglehart (2004) have suggested a different way of looking at the role of religion in the contemporary society. Their thesis is based on the argument that the development of countries is not universal, so the level of religiosity in a particular society is also different. To them secularization is much apparent in developed countries (with the exception of a few countries such as the USA, Poland, and Ireland). In the countries where the level of economic development is low, religiosity is still strong. Their thesis is: "Human development leads to cultural changes that drastically reduce religiosity and fertility rates" (Norris \& Inglehart 2004: 26). Nevertheless, the view that the level of development between countries is different, greatly articulates the determinant level of religiosity and, therefore, suggests that societies' cultures will never converge.

Whereas in the case of COVID-19 in the majority of developed countries a closure of religious institutions was adopted, in some developing countries such as Tanzania religious institutions remained open for believers to practice their faiths. The president of Tanzania was reported in several local and international media outlets as urging people to attend religious buildings, and he was also quoted as saying that COVID-19 is "satanic and therefore cannot thrive in churches" (Kombe in VOA News, March 27, 2020 04:29 pm). It was not only the developing countries that demanded the opening of religious institutions and buildings; in the USA a Florida pastor, Rodney Howard-Browne, refused to close down his church, and President Jair Bolsonaro of Brazil overruled the decision which was made by several state governors and the city mayor, exempting churches from the general closedown.

The emergence of COVID-19 is a perfect phenomenon to look at the role and expressions of religion in the twenty-first century. In his article "Viral visions and dark dreams: Ecological darkness and enmeshment in the time of COVID-19", Gentzke (2021) looks at COVID-19 as a disruption to self and the construction of meaning and values. For Gentzke, the pandemic has demonstrated the limitation of the authoritative discursive reason. The pandemic has also shown that the world is both connected and not converging at the same time, questioning Samuel P. Huntington's thesis about the clash of civilization (Huntington (1996). Huntington's cultural clash perspective was thought to be a major cause of international and domestic conflict (ibid.). This prediction has 
never materialized and instead we see an increase in the convergence of cultures, especially during the peak of COVID-19 period. Kearney (2021) asserts that COVID-19 has made things, such as religion and social relations, to be taken for granted, to be more desired and appreciated than before. McGrath (2021) says:

In this destitution, this suffering of the absence of God, Christians are never more Christian, never more followers of the Christ who redeemed the world by losing and becoming lost to the Father. (McGrath 2021:63)

As Norris and Inglehart (2004) noted, health problems are always linked to beliefs and practices, and COVID-19 has reaffirmed the role of religion in society during hard times and showed that, indeed, the role of religion is not passive but can be dominant in the public sphere. Milbank (2021: 78) asserts that "for many people, the pandemic is a warning of our disordered human relationship to life on earth".

The argument this work presents is that the forces of secularization have not managed to remove religion from its position in society at least in the times of major crises. Religion has played a significant role in explaining the mechanisms available against COVID-19, and provided an alternative way of coping and dealing with the pandemic. Findings from the field amplify this argument in a more empirical manner.

\section{METHODS AND MATERIALS}

This study employed a quantitative research approach, using the descriptive case study research design. The rationale for using this design and methodology is that the study focused on people and their beliefs, opinions, perceptions, and practices associated with their faith in the times of COVID-19. Therefore, we used a standardized data collection method for current fact-finding purposes. The study was conducted in Dar es Salaam region covering all the five districts: Ubungo, Temeke, Ilala, Kinondoni, and Kigamboni. The selection of the study sites was based on the trend that focused on high-intensity / high-risk areas. At the time of designing this study, the statistics showed that Dar es Salaam was the leading region in identifying victims of COVID-19. Other areas reported to have had documented victims of COVID-19 were Zanzibar, Arusha, Kagera, Tanga, and Mwanza.

The data were collected in June and July 2020, using a survey questionnaire in a sample of 258 respondents in Dar es Salaam region (Creswell 2003; Williams 2007). The survey questionnaires were distributed and filled out through 
face-to-face interaction between the researchers and respondents. The questionnaires were translated from English into the Kiswahili language to facilitate answering for the respondents. The data collected was entered into the Statistical Package for the Social Sciences (SPSS) software version 23. The analysis of the data focused on descriptive and inferential statistics, where descriptive data is presented in the form of frequencies and percentages in tables and diagrams, while inferential data is presented in a statistical significance form.

\section{RESULTS AND DISCUSSION}

\section{Socio-demographic characteristics of respondents}

A total of 258 respondents selected from five districts in Dar es Salaam region completed the social survey questionnaire. Demographic variables were recorded along with other factors regarding the populations' faith in terms of the COVID-19 pandemic.

Out of the 258 respondents that participated in the survey, 130 (50.4\%) were females and 128 (49.6\%) males. In this case, the number of the respondents was not significantly different in terms of gender. Most of the respondents' age ranged from 18 to above 60 years old, out of which $122(47.5 \%)$ were aged between 18 and 30 years old, 82 (31.9\%) aged between 31 and 40 years old, $35(13.6 \%)$ aged between 41 and 50 years old, 10 (3.9\%) aged between 51 and 60 years old, and 8 (3.1\%) aged 61 years old and above. In this study, the sampled youth were half of the population because according to the collective culture, young people are more easily accessible and were expected to be involved in administering preventive measures suggested in the country.

In terms of educational background, most of the respondents - $104(40.6 \%)-$ had completed secondary school level education, 75 (29.3\%) had completed tertiary education, $70(27.4 \%)$ had completed primary school level education, and $7(2.7 \%)$ had not completed any level of formal education. This shows that most respondents had received secondary education and were thus expected to be more knowledgeable about the preventive mechanisms and receptive to the government directives. Moreover, having more respondents with secondary education is attributed to the government's effort of offering universal education at primary and secondary levels. 


\begin{tabular}{|c|c|c|c|c|c|c|}
\hline Variable & Ubungo & Temeke & Ilala & Kinondoni & Kigamboni & \multirow[t]{2}{*}{ Total } \\
\hline \multirow{2}{*}{\multicolumn{6}{|c|}{ Frequency }} & \\
\hline & & & & & & $\operatorname{Sex}(n=258)$ \\
\hline Male & 28 & 30 & 29 & 21 & 20 & 128 \\
\hline Female & 28 & 30 & 31 & 29 & 12 & 130 \\
\hline \multicolumn{7}{|c|}{ Age (Years) $(n=257)$} \\
\hline $18-30$ & 33 & 24 & 24 & 21 & 20 & 122 \\
\hline $31-40$ & 14 & 19 & 21 & 21 & 7 & 82 \\
\hline $41-50$ & 6 & 12 & 10 & 4 & 3 & 35 \\
\hline $51-60$ & 0 & 3 & 2 & 4 & 1 & 10 \\
\hline $61+$ & 3 & 2 & 3 & 0 & 0 & 9 \\
\hline \multicolumn{7}{|c|}{ Education level $(\mathrm{n}=256)$} \\
\hline None & 0 & 0 & 1 & 5 & 1 & 7 \\
\hline Primary school & 7 & 23 & 26 & 0 & 5 & 70 \\
\hline Secondary school & 22 & 28 & 22 & 16 & 16 & 104 \\
\hline College or higher & 27 & 9 & 11 & 19 & 9 & 75 \\
\hline
\end{tabular}

Figure 1. Demographic characteristics of the respondents. Source: social survey June-July 2020. The number of respondents is different as in some cases answers were missing.

\section{Faith and COVID-19 in Tanzania: From believers' perspectives}

\section{Profiling respondents as per religious affiliation}

Respondents were asked to state the religious denomination to which they belong. The results indicate that $20 \%$ belonged to Christianity, $40 \%$ to Islam, while $20 \%$ belonged to other religions such as Hinduism, and $20 \%$ said that they did not belong to any religion (non-believers). Figure 2 gives a summary of religion distribution.

These results are attributed to the fact that Dar es Salaam is a region dominated by Muslims. The same applies to other coastal regions such as Pwani, Lindi, Mtwara, and Zanzibar. In the recent decades the Tanzanian government has removed religion-related statistics from the national census reports. The last census report conducted is from 1967, and it showed that the religious landscape in Tanzania was generally diverse, with 31\% Christians, 29\% Muslims, and 36\% believers of African religions; $1 \%$ were believers of other (mainstream) world religions, and 3\% belonged to other religions (Population Census 1967). Nevertheless, the Pew Forum on Religion \& Public Life published data on religious affiliations in Tanzania in 2009, and the results showed that $60 \%$ were Christians, $36 \%$ were Muslims, $2 \%$ were believers of traditional African 
religions, and $1 \%$ belonged to other religions. Figure 2 indicates that Muslims were twice as many as Christians in this study because, in the region where data collection was carried out, Muslims dominate other religious organizations. In conclusion, this indicates that Tanzania is a pluralistic country where many religions and believers coexist and practice their faiths.

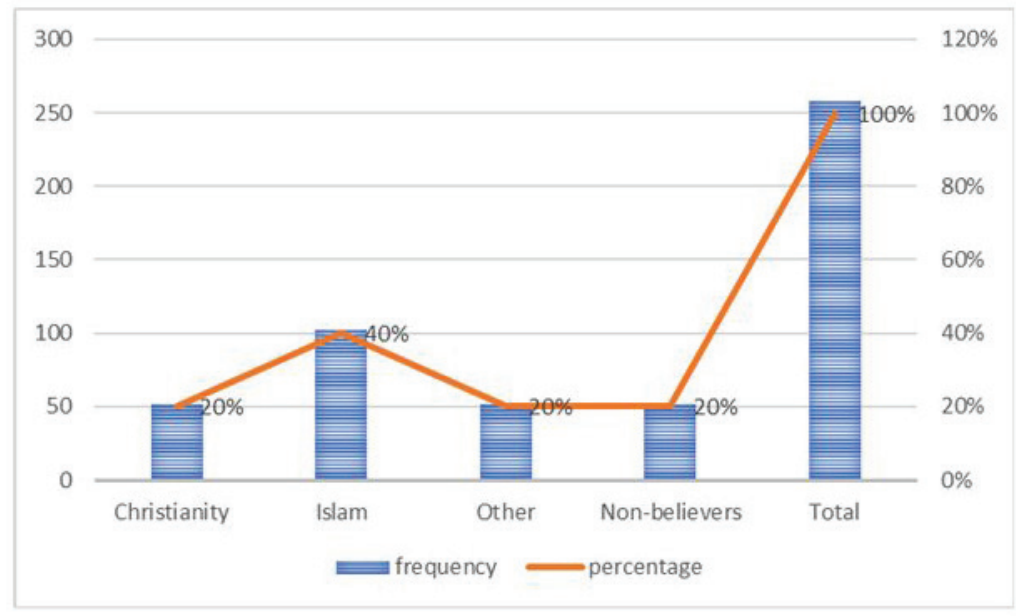

Figure 2. Respondents' distribution as per religious affiliation. Source: social survey June-July 2020.

\section{Participation in nationwide prayers against COVID-19 pandemic}

\section{in Tanzania}

The respondents were asked whether or not they participated in the nationwide prayers against the COVID-19 pandemic. The majority of them reported about participating in the nationwide prayers as indicated by $84.5 \%$ of the responses, while $15.5 \%$ did not participate. The possible explanation to this higher participation in national prayers against COVID-19 is the one provided by Kowalzyk et al. (2020), who note that once again religion became a source of solace during desperation, and, as Berger (2014) predicted, it resurfaced and became the dominant discursive resource for people to use. Nevertheless, the participation of Muslims, Christians, and people with other faiths (particularly indigenous non-Christian religions) in the national prayers was not common and can be attributed to the person who called for the countrywide prayer. The prayer was organized by the president of Tanzania and not by a religious leader. The fact 
that the call came from a political leader and not a religious leader provided a neutral ground and encouraged believers of different faiths to join in the announced practice. In this manner, such a prayer united all people regardless of their differences in faith. And henceforth, this contributed to eliminations of expressions of negative coping related to religion among people (e.g., accusing other groups which belong to different faiths). Later on, the President of Tanzania, Hon. Dr. John Pombe Magufuli, declared that Tanzania was coronavirusfree, and thanked the citizens for participating in the nationwide prayers. On Sunday, June 8, 2020 in Dodoma he said to the worshippers:

I want to thank Tanzanians of all faiths. We have been praying and fasting for God to save us from the pandemic that has afflicted our country and the World... I believe, and I'm certain that many Tanzanians believe, that the corona disease has been eliminated by God. (BBC News 2020)

Also, on July 20, 2020, President Hon. John Magufuli once again declared Tanzania to be coronavirus-free, and expressed his thanks to prayers by stating: "We decided to pray to God to save us from the Coronavirus (Covid-19). God has answered our prayers" (The Citizen 2020). This suggests that even the top leader of Tanzania was in support of prayers as a key tool to fight against the COVID-19 pandemic; hence it should not be surprising to see an increase in the rate of prayers during the COVID-19 pandemic in Tanzania.

Women's participation in nationwide prayers against COVID-19 was higher (52.8\%) than that of men (44.8\%). This is not surprising because even an earlier study by Trzebiatowska and Bruce (2013) reported that, despite being excluded from leadership positions in most cultures and religious settings, women tend to be more likely to pray and worship, and to claim that their faith is important to them. Moreover, in some cases women tend to dominate the world of spirituality. Even in normal circumstances, women's attendance in religious gatherings is higher than that of their spouses. Likewise, a study conducted by Zhang (2010) in China revealed that women have higher proportions of religious participation; however, the cognitive benefits of religious participation are stronger in the case of men. Other authors have attributed this fact to the patriarchal system and unequal power, whereby attending religious gathering provided solace to women in the context of powerlessness associated with the patriarchal system. Generally, the findings of our study and other global research suggest that women tend to participate more than men in religious practices, i.e., pray more and/or feel a greater presence of God in their everyday life (Forlenza \& Vallada 2018). This may be due to psychosocial differences between men and women, and thus, women's participation in prayers was at least partly a response to their anxiety due to the pandemic (Kowalczyk et al. 2020). 
Moreover, the percentage of respondents aged 18-30 years old participating in nationwide prayers was $47.4 \%$, followed by $31-40$-year-olds $(32.2 \%)$, while the ones aged 61+ years old participated the least (2.4\%) and the percentage of the rest of the age groups was $18 \%$. This finding may suggest that, in the times of crises like the COVID-19 pandemic, most people become more open to faith and prayers (cf. Kowalczyk et al. 2020). As Kowalczyk et al. (2020) reported, young people may participate more in prayers because of their belief that it will protect them from the coronavirus infection, while engaging in various economic activities such as trade and street vending. Again, provided that young people are less likely than older people to be seriously infected with COVID-19 (WHO 2020), the pandemic is still having a huge impact on the lives of the respondents in this age group, such as losing their loved ones or jobs. Additionally, the high rate of participation among young people in the nationwide prayers is associated with their supposed smaller vulnerability to COVID-19 infections than that of the other age groups such as the elderly, as reported by the WHO (WHO 2020). Therefore, they seemed to worry less about being infected with COVID-19 than other age groups, especially old people.

Initially, the general understanding about COVID-19 was that the pandemic affected a particular group of the population. This study aimed to understand the respondents' knowledge of this issue. The majority of the respondents $(62.6 \%)$ acknowledged the fact that the elderly are more vulnerable to the pandemic than other segments of the population (37.4\%). Figure 3 further illustrates the above argument by disaggregating respondents' knowledge of vulnerability in different age categories: children (4.7\%), the youth (2.3\%), and all people (29.8\%).

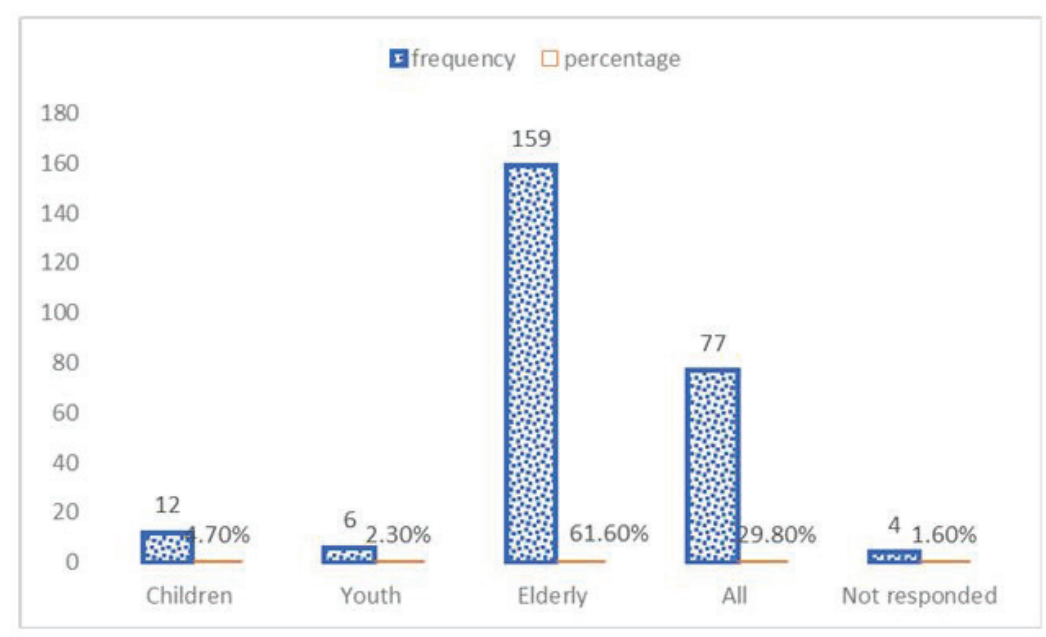

Figure 3. Knowledge about the age groups vulnerable to COVID-19 infections. Source: social survey June-July 2020. 
This result showed no statistical difference when cross-tabulated with gender, age, marital status, level of education, and residence $(\mathrm{P}>0.05)$. This finding from the respondents reproduced a picture that is being shared globally - the elderly are at a higher risk for COVID-19 infection.

\section{Types of religious practices against COVID-19 conducted}

\section{by the respondents}

When asked to mention the type of religious practices they participated in, $40.5 \%$ named religious gatherings; $25 \%$ fasted; $21.1 \%$ were engaged in home-based prayers, while $13.2 \%$ uttered daily prayers. Figure 4 summarizes the type of activities against COVID-19, in which the respondents participated.

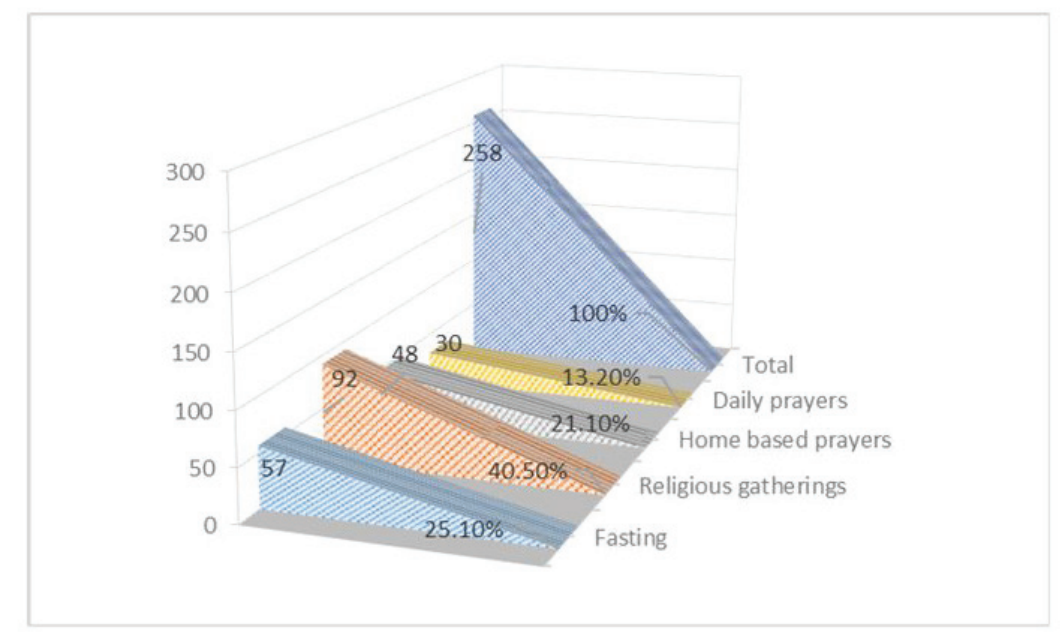

Figure 4. Types of prayer activities against COVID-19 pandemic. Source: social survey June-July 2020.

A possible explanation to this greater participation in religious gatherings against COVID-19 was provided by Isiko (2020), who is of the opinion that the COVID-19 pandemic has brought about common and practical needs at both the individual and community levels, which were meant to be met in order to defeat the pandemic.

In general, religious gatherings signified to people companionship, unity, commonness, togetherness, and socialization. These were powerful mechanisms during the period of COVID-19, when most individuals felt at least some degree 
of desperation. It implied that, despite the desperation, individuals were not alone and the message "we are in this together" was strongly echoed. In doing so, religion's status quo in the public domain was maintained, and thus principles of secularization did not deter the forces of religion in providing an alternative remedy in the time of pandemic, as summarized in Figure 5.

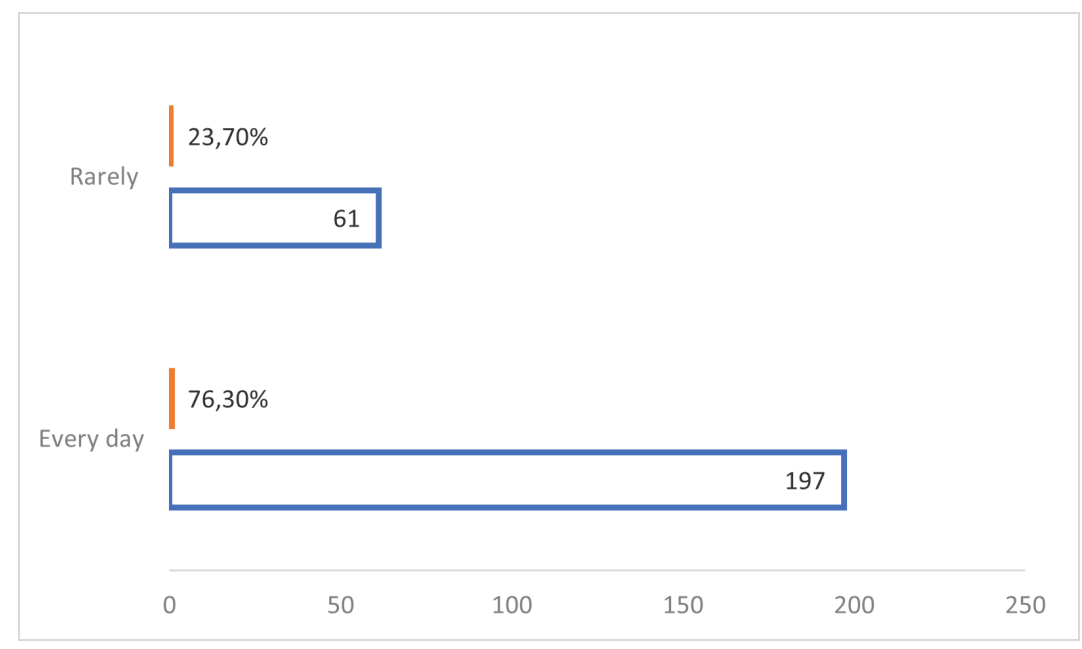

Figure 5. Frequency of prayer activities against COVID-19. Source: social survey June-July 2020.

When asked how often participants prayed against COVID-19, 76.3\% said they prayed every day, while $23.7 \%$ prayed rarely. These data indicated that the level of religiosity in Tanzania increased during the period of COVID-19. This result corroborates with the 2009 Pew Forum Survey on religion and public life, and answers the question asked by Meza (2020) about if in a pandemic people are more religious. This implies that the pandemic caused heavy insecurity and tensions in people and they opted for frequent prayers as a mechanism to reduce their tensions. Indeed, COVID-19 can be said to have increased religiosity in terms of increased frequency of prayers, attending religious gatherings, and participating in fasting. 


\section{CONCLUSION}

Our observations suggest that in general, Tanzanian population demonstrated intensified but still reasonable religious practices during the pandemic outbreak. The role of religion and God was emphasized in the public rhetoric, but it was a combination of religious and scientific strategies stressing the need for safe, medically grounded behavior (wearing masks, avoiding social contacts [shaking hands], closing of schools and colleges and constant hand washing). In that regard, based on the significance of positive religious practices, religious institutions are encouraged to maintain similar practices in other comparable situations. Correspondingly, there is an implication to the government and policy makers to ensure that these practices are framed and maintained for the benefit of and are in line with the culture and values of the Tanzanian society as well as scientific medical recommendations.

COVID-19 has reminded the researchers and the society alike of the increased role of faith in difficult times and in addressing health calamities. Although the pandemic imposed strains on the faith, people attempted to make adjustments within their capacities through prayers. It should be emphasized here that Tanzanians' engagement in religious practices is not only used for preventing and stopping physical diseases like COVID-19, but also for solving social, psychological, and interpersonal problems. The COVID-19 pandemic gives evidence of this attitude and behavior.

Furthermore, Tanzania's experience has discursively conveyed a picture that reproduced an ecumenic and pluralistic society whereby different religions converged in the fight against one enemy - COVID-19. Ecumenism and pluralism found a spontaneous expression supported by the public utterances of certain key persons (president of Tanzania, religious leaders), and religion was positioned positively as a source of solace, hope, unity, and stability, and thus dominated the public domain. This way religious beliefs contributed to cementing the country into a united nation.

\section{ACKNOWLEDGEMENTS}

We would like to express our heartfelt appreciation to the University of Dar es Salaam through the Directorate of Research and Knowledge Exchange for sponsoring our study on the preventive measures against COVID-19 in the context of scarcity and collective culture in Tanzania where we extracted the data for this paper. 


\section{NOTES}

1 See https://covid19.who.int/table, last accessed on 5 March 2021.

2 The statement first appeared in Nietzsche's 1882 collection titled "The Gay Science", which also translated as "The Joyful Pursuit of Knowledge and Understanding".

\section{REFERENCES}

BBC News 2020 = Coronavirus: John Magufuli Declares Tanzania Free of Covid-19. BBC.com, 8 June. Available at https://www.google.com/amp/s/www.bbc.com/news/ amp/world-africa-52966016, last accessed on 8 March 2021.

Berger, Peter L. 2014. The Many Altars of Modernity: Toward a Paradigm for Religion in a Pluralist Age. Boston \& Berlin: Walter de Gruyter.

Creswell, John W. 2003. Research Design: Qualitative, Quantitative, and Mixed Method Approaches. London: SAGE Publications.

DeFranza, David \& Lindow, Mike \& Harrison, Kevin \& Mishra, Arul \& Mishra, Himanshu 2020. Religion and Reactance to COVID-19 Mitigation Guidelines. American Psychologist. Advance online publication. http://dx.doi.org/10.1037/amp0000717.

Durkheim, Emile 1995 [1915]. Elementary Forms of Religious Life. Transl. by Karen E. Fields. New York: The Free Press.

Forlenza, Orestes V. \& Vallada, Homero 2018. Spirituality, Health and Well-Being in the Elderly. International Psychogeriatrics, Vol. 30, No. 12, pp. 1741-1742. http:// dx.doi.org/10.1017/S1041610218001874.

Ganiel, Gladys \& Winkel, Heidemarie \& Monnot, Christophe (eds.) 2014. Religion in Times of Crisis. Leiden: Brill. https://doi.org/10.1163/9789004277793.

Gentzke, Joshua L.I. 2021. Viral Visions and Dark Dreams: Ecological Darkness and Enmeshment in the Time of COVID-19. In: Alexander J. Hampton (ed.) Pandemic, Ecology and Theology: Perspectives on COVID-19. New York: Routledge, pp. 4-16.

Gorski, Philip S. 2003. Historicizing the Secularization Debate: A Program for Research. In: Michele Dillon (ed.) Handbook of the Sociology of Religion. New York \& Cambridge, UK: Cambridge University Press, pp. 110-122. https://doi. org/10.1017/CBO9780511807961.009.

Huntington, Samuel P. 1996. The Clash of Civilizations and the Remaking of World Order. New York: Simon \& Schuster.

Isiko, Paulo Alexander 2020. Religious Construction of Disease: An Exploratory Appraisal of Religious Responses to the COVID-19 Pandemic in Uganda. Journal of African Studies and Development, Vol. 12, No. 3, pp. 77-96. https://doi.org/10.5897/ JASD2020.0573.

Kearney, Richard 2021. What Happened to Touch? In: Alexander J. Hampton (ed.) Pandemic, Ecology and Theology: Perspectives on COVID-19. New York: Routledge, pp. 29-40.

Kombe, Charles 2020. Tanzanian President Criticized for Refusing to Close Places of Worship. VOA News, 27 March. Available at https://www.voanews.com/sciencehealth/coronavirus-outbreak/tanzanian-president-criticized-refusing-close-placesworship, last accessed on 15 March 2021. 
Kowalczyk, Oliwia \& Roszkowski, Krzysztof \& Montane, Xavier \& Pawliszak, Wojciech \& Tylkowski, Bartosz \& Bajek, Anna 2020. Religion and Faith Perception in a Pandemic of COVID-19. Journal of Religion and Health, Vol. 59, No. 6, pp. 26712677. https://doi.org/10.1007/s10943-020-01088-3.

Lawi, Yusuf 2015. Trends and Patterns in Religious Conflicts in Tanzania from the Colonial Past to the Present. In: R. S. Mukandala (ed.) The Political Economy of Change in Tanzania: Contestations over Identity, the Constitution and Resources. Dar es Salaam: University of Dar es Salaam, pp. 13-34.

Marx, Karl 1964. On Religion. In: S. Ryazanskaya (ed.) The German Ideology. Moscow: Progress Publishers.

Mbiti, John S. 1969. African Religion and Philosophy. Nairobi: East African Educational Publishers.

McGrath, Sean J. 2021. Eschatology in a Time of Crisis. In: Alexander J. Hampton (ed.) Pandemic, Ecology and Theology: Perspectives on COVID-19. New York: Routledge, pp. 54-65.

Meza, Diego 2020. In a Pandemic Are We More Religious? Traditional Practices of Catholics and the COVID-19 in Southern Colombia. International Journal of Latin American Religion, Vol. 4, No. 2, pp. 218-234. https://dx.doi.org/10.1007\% 2Fs41603-020-00108-0.

Milbank, John 2021. Between Catastrophes: God, Nature and Humanity. In: Alexander J. Hampton (ed.) Pandemic, Ecology and Theology: Perspectives on COVID-19. New York: Routledge, pp. 78-89.

Mills, Wright C. 1959. The Sociological Imagination. Oxford: Oxford University Press. Ndaluka, Thomas J. 2012. Religious Discourse, Social Cohesion and Conflict: MuslimChristian Relations in Tanzania. Berlin: LIT Verlag.

Ndaluka, Thomas J. 2015. Social Cohesion and Religious Intolerance in Tanzania. In: R. Mukandala (ed.) The Political Economy of Change in Tanzania: Contestation over Identity, the Constitution, and Resources. Dar es Salaam: University of Dar es Salaam Press, pp. 35-54.

Nietzsche, Friedrich 2020. God is Dead. God Remains Dead. And We Have Killed Him. Transl. by R. Kevin Hill and Michael A. Scarpitti. UK: Penguin Books Limited.

Norris, Pippa \& Inglehart, Ronald 2004. Sacred and Secular: Religion and Politics Worldwide. Cambridge: Cambridge University Press.

Population Census $1967=$ United Republic of Tanzania 1967. Population Census. Dar es Salaam: National Bureau of Statistics.

Sundqvist, Josephine 2017. Beyond an Instrumental Approach to Religion and Development: Challenges for Church-Based Healthcare in Tanzania. Uppsala: Uppsala University.

The Citizen 2020 = President Magufuli Declares Tanzania Free from Covid-19. The Citizen, 20 July. Available at https://www.google.com/amp/s/www.thecitizen. co.tz/tanzania/news/president-magufuli-declares-tanzania-free-from-covid-19$2712972 \% 3 \mathrm{fview}=$ htmlamp, last accessed on 8 March 2021.

Trzebiatowska, Marta \& Bruce, Steve 2013. Why Are Women More Religious Than Men? Oxford Scholarship Online. https://doi.org/10.1093/acprof:o so/9780199608102.001.0001.

Weber, Max 1963. The Sociology of Religion. Boston: Beacon Press.

WHO 2020 = Engaging Young People in the Response to COVID-19 in WHO's Eastern Mediterranean Region. WHO Regional Office for the Eastern Mediterranean. 
Available at http://www.emro.who.int/media/news/engaging-young-people-in-theresponse-to-covid-19-in-whos-eastern-mediterranean-region.html, last accessed on 9 March 2021.

Williams, Carrie 2007. Research Methods. Journal of Business \& Economics Research, Vol. 5, No. 3, pp. 65-72. https://doi.org/10.19030/jber.v5i3.2532.

World Bank 2013 = Private Health Sector Assessment in Tanzania. Compiled by James White \& Barbara O'Hanlon \& Grace Chee \& Emmanuel Malangalila \& Adeline Kimambo \& Jorge Coarasa \& Sean Callahan \& Ilana Ron Levey \& and Kim McKeon. Washington DC: The World Bank. Available at http://documents1. worldbank.org/curated/en/888021468132272587/pdf/Private-health-sectorassessment-in-Tanzania.pdf, last accessed on 15 March 2021.

Zhang, Wei 2010. Religious Participation, Gender Differences, and Cognitive Impairment among the Oldest-Old in China. Journal of Aging Research, Vol. 2010. Online. https://doi.org/10.4061/2010/160294.

Thomas J. Ndaluka works at the University of Dar es Salaam as a lecturer and coordinator of the Society and Religion Research Centre (SORRECE). His research interest is in the areas of social identity, religious relations and conflicts, gender, and critical discourse analysis. He is the author of the book entitled: "Religious Discourse, Social Cohesion and Conflict in Tanzania: Muslim - Christian Relations in Tanzania" (2012, LIT, Berlin) and co-editor of the book entitled "Religion and State Revisited in Tanzania": Reflection from 50 Years of Independence" (2014, LIT, Berlin).

ndaluka.thomas@udsm.ac.tz

Magolanga Shagembe is assistant lecturer in psychology at the University of Dar es Salaam, and Secretary General of the Tanzanian Psychological Association (TAPA). His research interest is in the areas of child development and learning, adolescence, ageing, people's behavior at the workplace, social behaviors and guidance and counselling.

shagembe.magolanga@udsm.ac.tz

Jonas Kinanda is assistant lecturer in psychology and coordinator of the Unit of Psychology at the University of Dar es Salaam. His research interest is in the areas of emotional and behavioral disorders, positive psychology, ageing, guidance and counseling, psychosocial support, sexuality, and career development.

kinandajj@gmail.com

Vendelin Simon is lecturer and coordinator of the Unit of Anthropology at the University of Dar es Salaam. His research interest is in the areas of gerontology, social impact assessment, and religion and livelihood assessment.

vendelin.simon@yahoo.com 